\title{
Bureaucratic Rents and Life Satisfaction
}

\author{
Simon Luechinger* \\ University of Zurich \\ Stephan Meier ${ }^{\star *}$ \\ Federal Reserve Bank of Boston \\ Alois Stutzer ${ }^{\star * *}$ \\ University of Basel
}

Institutions affect bureaucrats' possibilities to acquire rents; they determine the degree of accountability and responsiveness of officials and of political control of the bureaucracy and, thereby, the size and distribution of rents in the public sphere. Those rents can involve higher wages, monetary and nonmonetary fringe benefits, and bribes. We propose a direct measure to capture the total of these rents: the difference in subjective well-being between bureaucrats and people working in the private sector. In a sample of 42 countries, we find large variations in the extent of rents in the public bureaucracy. The extent of rents is determined by differences in institutional and political constraints. In particular, we find judicial independence to be of major relevance for a tamed bureaucracy. Further, our measure for rents correlates with indicators of regulatory policies and perceptions of corruption. (JEL D72, D73, I31, J30, J45)

\footnotetext{
*Institute for Empirical Research in Economics, University of Zurich, Zurich, Switzerland. Email: sluechinger@iew.unizh.ch.

**Center for Behavioral Economics and Decision Making, Federal Reserve Bank of Boston, Boston, MA. Email: stephan.meier@bos.frb.org.

***Department of Business and Economics University of Basel, Basel, Switzerland. Email: alois.stutzer@unibas.ch.

We are grateful to Iwan Barankay, Christine Benesch, Matthias Benz, Tim Besley, Andrew Clark, Robert Dur, Reiner Eichenberger, Bruno Frey, Simon Hug, Rafael Lalive, Erzo Luttmer, Dennis Mueller, Susanne Neckermann, Susan Rose-Ackerman, Friedrich Schneider, Reto Tanner, Ruut Veenhoven, Rainer Winkelmann, participants of the 2006 American Social Science Association meeting, the 2006 meeting of the Comparative Law and Economics Forum, the 2006 meeting of the European Public Choice Society, seminar participants at the London School of Economics, the Swiss Federal Institute of Technology Zurich and the universities of Basel, Bern, Fribourg, Rotterdam and Zurich, two anonymous referees, and the editor Pablo Spiller for helpful comments. Our special thanks go to Carol Graham and Andrew Felton for providing valuable information on life satisfaction in Latin America. The views expressed herein are solely those of the authors and not those of the Federal Reserve System or the Federal Reserve Bank of Boston.
}

The Journal of Law, Economics, \& Organization, Vol. 24, No. 2, doi:10.1093/jleo/ewm057

Advance Access publication December 2, 2007

(C) The Author 2007. Published by Oxford University Press on behalf of Yale University.

All rights reserved. For permissions, please email: journals.permissions@oxfordjournals.org 


\section{Introduction}

According to a political economics view, the extent to which government employees can acquire rents and protect them against dissipation is essentially determined by the institutional environment. Institutions affect the accountability and responsiveness of officials to citizens and interest groups and, thus, determine the size of the rents created. Further, institutions influence the degree of political control of public bureaucrats and, thus, the distribution of rents within the public sphere.

In order to understand the restrictions to rent seeking of government sector employees, direct measures of rents are desirable. Rents, or utility premiums of government sector workers relative to private sector workers, can consist of wage differentials, monetary fringe benefits, nonmonetary job amenities, and possibilities for extracting bribes. Approaches based on wage differentials cannot capture all those benefits, or are not applicable, because they start from a competitive equilibrium without rents; they offer no guidance in interpreting any wage differential, either in terms of a rent or compensation. Job queues potentially capture the total rent, but only for the marginal position and if government jobs are not allocated by cronyism. Setting reported bureaucratic corruption equal to rents is not appropriate either because it is not clear whether corruption leads to extra benefits for public employees.

This article pursues two goals. (1) As a direct measure for bureaucratic rents, we propose the difference in subjective well-being between public and private sector employees of a country. If bureaucrats report higher life satisfaction, this differential is interpreted as a utility premium, or simply a rent. It is argued that employees in the government sector benefit from higher rents in countries where there is a larger positive gap in reported life satisfaction, ceteris paribus. In contrast to previous approaches for measuring rents, our approach has the advantage of measuring the total net utility differential between people working in the government and the private sector. (2) We analyze the conditions determining the rents in the public bureaucracy in a cross section of 25 European and 17 Latin-American countries. The life satisfaction differentials between privately and publicly employed people are related to institutional and political factors that are proposed as effective controls, guaranteeing efficiency in the government sector. In particular, we study empirically (1) political control when the interests of the legislature and the executive are aligned, (2) the role of an independent judiciary, (3) the relation to specific policies, and (4) whether rents are appropriated via corruption.

Section 2 sketches various theories explaining the existence of rents in the government sector. Section 3 introduces our measure for capturing rents. Section 4 presents the empirical analysis and Section 5 offers concluding remarks.

\section{Theories of Bureaucratic Rents}

Rent-seeking activities aim at securing private benefits through state activities. Though individually rational, rent seeking is socially wasteful. Investments in the rent-seeking contest divert resources from their productive use, and the 
resulting regulations induce market distortions. Rent-seeking activities not only affect the wealth distribution within the private sector but also are expected to reduce the level of welfare in the private sector overall. Winners of the rent-seeking contest and their employees might be better off, but the unsuccessful contestants and the unorganized citizens lose. Rent-seeking activities also lead to a redistribution between the private and the government sector. We focus on this latter aspect of rent seeking. Investments in rent seeking by interest groups can take the form of campaign contributions, hiring the relatives of officials, employing the officials themselves upon retirement, or bribes. Therefore, elected officials and bureaucrats are beneficiaries of rentseeking activities.

Bureaucrats play an important role on the supply side of the political market for rent-creating government interventions. On the one hand, bureaus have substantial policy-implementing authority, making them a worthwhile target for rent-seeking activities. On the other hand, the policies resulting from the rent-seeking process, even if brokered by elected officials, create valuable property rights. Bureaucrats can extract part of the created rents, insofar as they have discretion over the provision of these property rights. Rents of government employees thus depend (1) on the extent to which rents are transferred from the private to the public sphere and (2) how they are shared between politicians and the bureaucracy.

\subsection{Political Checks and Balances}

There are two opposing perspectives on how to best deal with the agency problems inherent in representative democratic governance. In a first perspective, separation of powers with competition between political institutions in a system of checks and balances is assumed to make it more difficult for politicians to collude with each other at the voters' expense. So politicians can extract less rents, bureaucrats can share in (Buchanan and Tullock 1962; Persson and Tabellini 2004). A second perspective sees the remedy in electoral competition between relatively few political parties in a centralized political system. Voters make politicians responsible for government services and rely on their clear lines of authority vis-à-vis the bureaucracy (Downs 1957; Olson 1982; Kuniková and Rose-Ackerman 2005).

How rents are shared depends on the political control of the bureaucracy by the executive and the legislator. Politicians apply a wide set of strategies including the competition for budgets among bureaus, ex post sanctions, and enfranchising the politically relevant constituencies in the administrative process which monitor bureaus' behavior (Weingast and Moran 1983; McCubbins et al. 1987; de Figueiredo et al. 1999). The form of democratic governance and the political control of the bureaucracy including its organization and processes are, however, interrelated (e.g., Moe and Caldwell 1994; Spiller and Urbiztondo 1994). More or less competition between the legislature and the executive provides specific incentives to politicians in their effort to design an accountable bureaucracy in order to pursue their policy preferences (Lupia 
and McCubbins 1994). In the literature, the efforts of the executive and the legislature to control the bureaucracy are often discussed referring to the distinction between a presidential and a parliamentary system. It is hypothesized that the more the principals' interests diverge, the easier it is for government employees to acquire rents. Under separation of power with weak legislators, bureaucrats are able to play politicians in the executive and legislative branches off one another in the attempt to maximize their discretion. The tendency of opposing interests between the executive branch and the legislator in a presidential system fuels legislator's activism to protect its interest in the bureaucracy. Legislators impose detailed rules of procedure that are difficult to alter by the executive. Political control of the bureaucracy, however, is thereby hampered. Thus, although the separation of power in a presidential system might reduce the total rents in the political system, bureaucrats are expected to face weaker political control when they try to share in. The same holds if the argument is generalized to multiple lines of control in a system of checks and balances between the executive and the legislature or when the party control of the executive and legislative branches are divided rather than unified. ${ }^{1}$

\subsection{Judicial Independence}

A less ambiguous prediction for bureaucratic rents emerges if the separation of powers is understood to include an independent judiciary. Courts have several instruments at their disposal to review and revise decisions of politicians and bureaus and thus effectively influence policy making. They can rule on the constitutionality of a statute, on whether actions by regulatory agencies are consistent with existing law or agencies have followed the appropriate process in making its decision (Tiller 1998; Hanssen 2000). However, politicians can override disagreeable rulings and take reprisals. This triggers strategic interaction between the court and the other actors. In order to avoid legislative overrides, courts have to consider the political interests of the other institutions of government. Hence, the court can only choose those points in the policy space from which it is not possible to deviate without reducing the utility of at least one veto player. Similarly, in administratively implementing a policy, the executive or bureaus anticipate the further evolution of the strategic interaction (Gely and Spiller 1990).

In general, the existence of an additional independent player, the judiciary, decreases bureaucratic rents. ${ }^{2}$ Judicial review restricts the discretion of the player implementing a statute because the additional player's ideal point

1. The arguments can, of course, be refined to take into account the many differences within the two baseline models of representative democracy, with regard to electoral rules, the strength of regional legislative representation, and so on.

2. Landes and Posner (1975) argue that an independent judiciary can also facilitate rent extraction by the other branches. It immunizes laws from short-run political pressures and thereby increases the value of legislation sold to interest groups. 
has to be considered. ${ }^{3}$ It restricts agencies' discretion in policy implementation and thus rent-creating possibilities directly in situations in which elected officials do not fully control the bureaucracy (Spiller 1992); it restricts bureaucratic rents indirectly by reducing overall transfers from the private to the public sectors in situations of tight political control of bureaus.

The relation between judicial independence and political checks and balances or political fragmentation is often analyzed applying spatial models. There, it is only the disalignment of preferences of the other political actors that opens a set of policy points from which the judiciary can choose without fear of reversals (Iaryczower et al. 2002). There are, however, also separate institutional factors determining judicial independence. These factors can influence both, judges' desire and ability to challenge the elected officials' decisions, that is, they shape the constraints on judicial decision making and judges' political alignment. Tenure of judges and nomination provisions, for example, affect the degree to which judges' preferences are aligned with those of the relevant political actor. Therefore, depending on these provisions one might observe a docile judiciary even in a fragmented environment. In contrast, majority requirements for legislative overrides and transaction costs in negotiating political deals shield the judiciary apart from the level of political fragmentation. High transaction costs might make decisions against the government's interests feasible even in times of political cohesiveness. This latter aspect is especially important as in this way an independent judiciary can serve as a means to break up politicians' and bureaucrats' cartel against citizens.

\subsection{Regulatory Policies}

Bureaucratic rents depend on the institutional framework but are finally created by specific regulations and acquired in a specific form. The main rent-creating government interventions analyzed in the literature are policies sheltering firms from competition (Tullock 1967). Strict regulations function as barriers to entry and, hence, increase incumbent firms' profits. As there is a constant threat that the rents will be annihilated, interest groups have an incentive to strike bargains with the bureaucrats (McChesney 1987). Moreover, the higher the rents created by government intervention, the higher are the incentives for bureaucrats to engage in malfeasant behavior (Ades and Di Tella 1999). The level of rents is thus expected to be the higher, the more domestic competition is hampered by regulatory policies.

\subsection{Corruption}

A mean to exploit bureaucratic discretion is to require irregular payments or bribes (e.g., Rose-Ackerman 1999). It is, however, an empirical question whether bureaucrats can acquire rents via corruption or whether gains from corruption are either dissipated or compensate for lower salaries.

3. Tiller and Spiller (1999) point out that agencies can retain some discretion by strategically choosing more burdensome regulatory instrument if such choice imposes even greater relative costs on judicial reversal. 
2.5 Alternative Causes for Utility Premiums in the Bureaucracy and Rent Dissipation There are many other sources that affect the well-being of government sector employees. They may, for example, enjoy social respect from their fellow citizens and be intrinsically motivated. Empirically, we take these effects into account as level effects as there is no obvious reason to believe that they are systematically related to political control.

Despite the limited political control to bureaucratic rent seeking, it is not clear whether bureaucrats succeed in capturing any rents at all. The rents may be dissipated in the process of acquiring and defending them (Buchanan 1980). Therefore, whether and under what conditions bureaucrats are able to capture rents are ultimately empirical questions.

\section{Measurement of Rents in the Public Bureaucracy}

The economic idea of a rent is a utility premium an individual can appropriate due to his or her monopolistic position or informational advantage. We propose to approximate this utility premium by the relative difference in reported life satisfaction between public and private employees. ${ }^{4}$ Behind the score indicated by a respondent lies a cognitive assessment on the extent to which she judges the overall quality of her life in a favorable way. The measures of reported subjective well-being passed a series of validation exercises and seem to significantly correlate with true-positive inner feelings (see Frey and Stutzer 2002 for a survey on happiness economics and references to the validation literature). Focusing on life satisfaction allows us to capture the total net benefits of a position in the public bureaucracy. Thereby, benefits can go beyond the immediate job, for example, due to advantages on the housing market or utilization of public services, like education for one's children, and pension benefits. ${ }^{5}$ This "all-inclusive" aspect differentiates our approach from research studying the job satisfaction of public and private sector employees (Heywood et al. 2002; Clark and Senik 2004).

Our empirical strategy to measure rents in the bureaucracy can be summarized as follows. The utility or life satisfaction increment or decrement from government sector employment is isolated in a multivariate regression. The life satisfaction ${ }_{i j}$ of individual $i$ living in country $j$ is explained by a dummy variable that takes on the value 1 if he or she is a bureaucrat and 0 otherwise and a vector of other personal characteristics $\boldsymbol{Z}_{i j}$ along which individuals in the two sectors might differ from one another and which have an impact on reported life satisfaction, such as sex, age, education, marital status, type of neighborhood, and citizenship status. Income, working hours, and occupation are not included as control variables because these job characteristics may be important channels through which rents are appropriated. If these job characteristics were held constant, the pervasiveness of any rent in the government sector would be underestimated. All control variables are transformed into

4. In a competitive market equilibrium with homogenous agents, we expect no difference in reported life satisfaction between the two sectors and thus no systematic rents.

5. The approach also allows us to capture any disutility from working in the public bureaucracy. 
mean deviation form, $\mathbf{Z}_{i j}-\overline{\mathbf{Z}}_{j}$. The coefficient of the constant term, $\beta_{0 j}$, can thus be interpreted as the life satisfaction of the average individual living in country $j$, if he or she were to work in the private sector. In order to allow for country-specific effects of government sector employment, as well as for the control variables on life satisfaction, the regression summarized in the equation (1) is run for each country $j$ separately:

Life satisfaction $_{i j}=\beta_{0 j}+\beta_{1 j}$ bureaucrat $_{i j}+\beta_{2 j}\left(\mathbf{Z}_{i j}-\overline{\mathbf{Z}}_{j}\right)+\varepsilon_{i j}$.

With the estimated coefficients of the microeconometric well-being function, the percentage difference in life satisfaction due to public employment in country $j, \Delta_{j}$, can be calculated as follows:

$\hat{\Delta}_{j}=\hat{\beta}_{1 j} / \hat{\beta}_{0 j}$.

Calculating a relative difference within countries cancels out any country- or culture-specific response effect. We propose the relative satisfaction differential $\hat{\Delta}_{j}$ as a proxy for rents in the public sector. Standard errors (SEs) for the relative differentials are computed using the delta method.

\section{Empirical Analysis}

\subsection{Data}

In our empirical analysis, we use data from the first two waves of the European Social Survey (ESS) for 25 European countries (2002/3 and 2004/5) and the Latinobarometer (LB) for 17 Latin-American countries (waves 1997, 2000, 2001, and 2003). For robustness checks, we also use the Eurobarometer (EB) with information for 13 European countries (14 waves between 1989 and 1994). Life satisfaction is reported in the ESS using the following question: "All things considered, how satisfied are you with your life as a whole nowadays?" Individuals are asked to state their life satisfaction on a scale from 0 (extremely dissatisfied) to 10 (extremely satisfied). The questions asked in the other survey series are similar, though responses are elicited on a four-point scale. In the analysis, the sample is restricted to employed and self-employed individuals. ${ }^{6}$ A dummy variable indicates whether an individual is working in the public bureaucracy. In the ESS, the variable is constructed on the basis of information about the respondents' industry. It includes people working in the public administration, defense, and compulsory social security. There are 39,925 observations from the ESS; 2695 individuals are classified as bureaucrats. In the case of the LB and the EB, the variable is constructed on the basis of information about the respondents' sector of employment. This categorization of the bureaucracy does not only include public administration but also

6. This restriction leads to lower bound estimates of bureaucratic rents for two reasons. First, former government sector employees usually enjoy exceptionally generous retirement provisions. Second, public officials are often protected from dismissal by special statutes. Hence, former bureaucrats will be underrepresented among unemployed people. Generous retirement arrangements and greater job security are both likely to be important aspects of bureaucratic rents. 


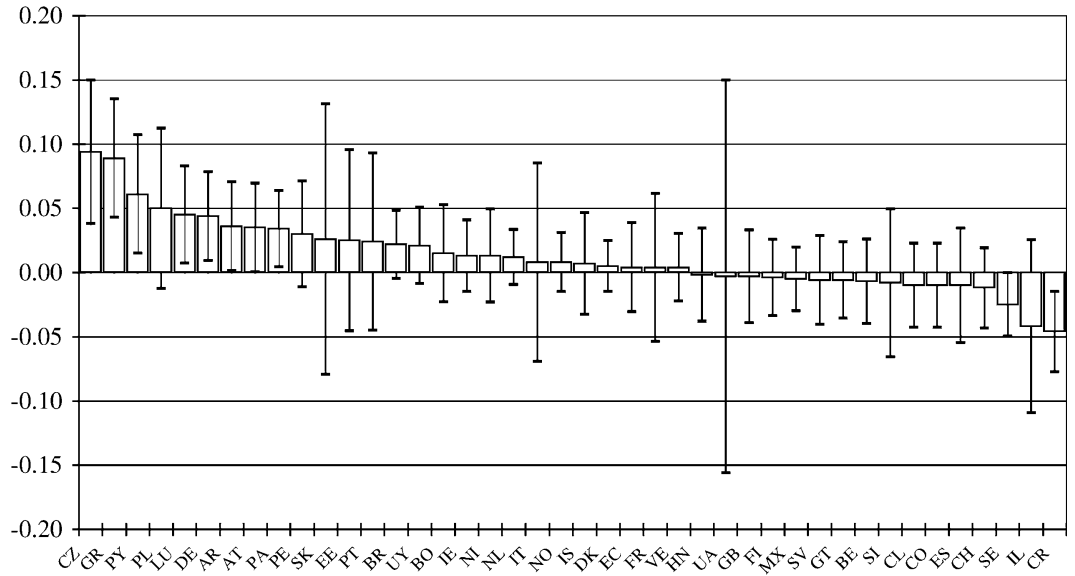

Figure 1. Relative Life Satisfaction Differentials for Europe and Latin America.

Notes: (1) This graph plots estimates for the relative life satisfaction differentials and the corresponding $90 \% \mathrm{Cl}$; (2) the SEs of the relative differentials are computed using the delta method. Sources: ESS 2002/3 and 2004/5 and Graham and Felton (2005) based on LB 1997, 2000, 2001, and 2003.

public sector employment in total. The four waves of the LB used contain 40,539 observations with 6587 public sector employees.

\subsection{Measurement of Rents in the Public Bureaucracy}

Figure 1 presents the estimated relative utility differentials for the individual countries. There are four countries with life satisfaction differentials for public employees that are plus 5\% or larger. These are the Czech Republic, Greece, Paraguay, and Poland. At the other end of the spectrum, there are countries in which it is more attractive to work in the private sector. For Sweden, Israel, and Costa Rica the relative differentials are around $-2 \%$ to $-5 \%$. The relative gaps in life satisfaction are measured with different degrees of precision, reflected in the confidence interval (CI) for each estimation. These variations in the SEs of the relative differentials are taken into account in the next step of the analysis.

\subsection{Determinants of Rents in the Government Sector}

This section tests the determinants of rents discussed in Section 2. Rents in the government sector, the dependent variable, are taken from our first step estimations for single countries. As the dependent variable is measured with unequal precision across countries, we have to correct for heteroskedasticity. We estimate general least squares (GLS) models and use the inverse of the estimated SEs of the relative life satisfaction differentials as weights. We include a dummy variable for Latin-American countries and the log of GDP per capita in the baseline specification. As economic development is an important summary measure for a functioning state and economy, this ensures that we study the determinants of rents for economically comparable countries and are not just picking up the effect of economic development. 
4.3.1 Political Checks and Balances. Rents in the government sector are hypothesized to depend on two countervailing effects of the political checks and balances in a country (see Section 2.1). Regarding political checks and balances, a basic distinction is between a presidential and a parliamentary system. Although indicators for this institutional difference are readily available, an econometric identification of the consequences of this specific institutional difference is not possible in the sample at hand. The reason is that Latin-American countries adopted presidential systems, whereas European countries mainly chose parliamentary systems. However, it is possible to study the political checks and balances emerging from an alignment or disalignment of the political preferences of the executive and the legislature. We construct a variable based on data from Henisz (2002). Alignment takes on a value 1 if the executive is aligned with at least one legislative chamber and 0 otherwise. Table 1 shows that the relative life satisfaction differential is 3.6 percentage points larger in countries where the executive and the legislature are dominated by the same party. However, the difference is not statistically significant.

4.3.2 Judicial Independence. For judicial checks, we estimate large negative effects on the proxy for rents. The first variable measures judicial independence, or the absence of interference by the government or parties in disputes. The second measures the extent to which a trusted legal framework exists for private business to challenge the legality of government actions or regulations. Both measures are based on the perceptions of business executives about the judicial system in the country they operate (Gwartney and Lawson 2004). ${ }^{7}$ The decrement of the differential for an increase of the indicators by 1 standard deviation (SD) amounts to 3.2 percentage points for judicial independence and 3.6 percentage points for impartial courts. Although the degree of judicial independence depends on the political checks and balances, it is not fully determined by them. Therefore, we take both institutional aspects jointly into account in the estimation equation. Judicial independence is still related with lower rents in the public bureaucracy. The positive effect for alignment is now statistically significant. If political checks and balances are undermined by an executive and legislature that are dominated by the same party, rents are estimated to be higher, ceteris paribus.

4.3.3 Regulatory Policies. Columns VI and VII in Table 1 show that rents in the public sector are systematically related to policies protecting firms from competition. We use two variables based on business executives' perceptions (1) on how easy it is in general to start a new business and (2) on the prevalence of price controls (Gwartney and Lawson 2004). We find that rents are lower when it is easier to start a business and higher when price controls are more widespread. A change of the former indicator by $1 \mathrm{SD}$ is related to

7. All indices from Gwartney and Lawson (2004) are rescaled such that they take on values between 0 and 10 with 0 meaning, for example, the least independent. 
Table 1. Checks and Balances and Rents in the Public Bureaucracy

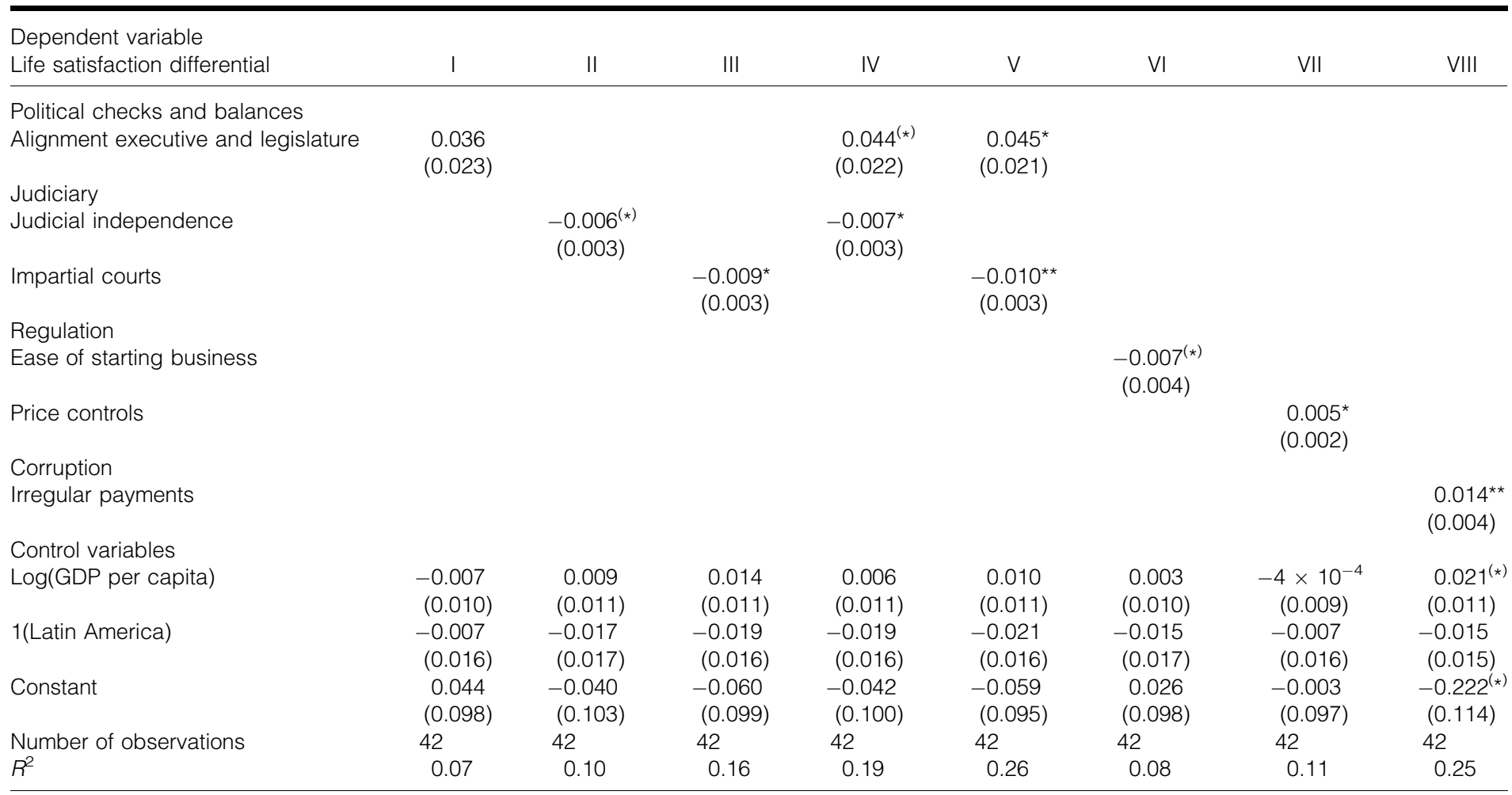

GLS estimations; ${ }^{* \star} p \leq 0.01,{ }^{\star} 0.01<p \leq 0.05$, and ${ }^{(*)} 0.05<p \leq 0.1$; SE in parentheses. Sources: ESS 2002/3 and 2004/5, Graham and Felton (2005) based on LB 1997, 2000, 2001 and 2003; Henisz (2002); Heston et al. (2002); and Gwartney and Lawson (2004). 


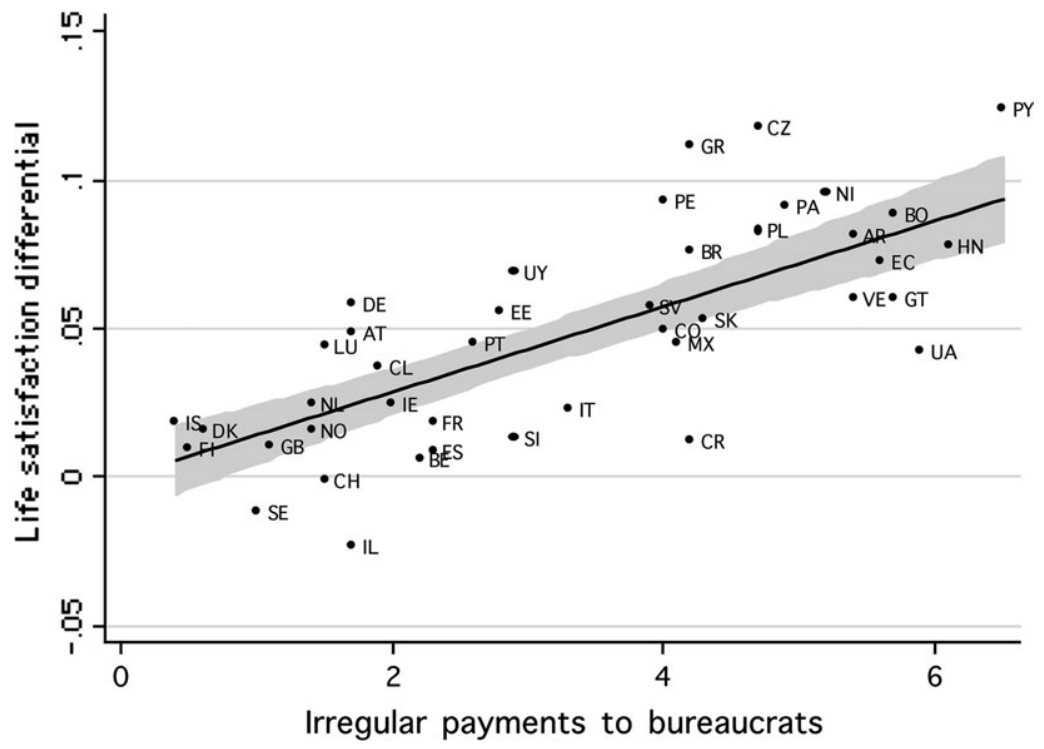

Figure 2. Corruption and Rents in the Public Bureaucracy.

Notes: (1) GLS estimation; (2) shaded area is $95 \% \mathrm{Cl}$; (3) life satisfaction differentials are corrected for log(GDP per capita) and separate constants for Europe and Latin America, respectively. Sources: ESS 2002/3 and 2004/5; Graham and Felton (2005) based on LB 1997, 2000, 2001, and 2003; Heston et al. (2002); and Gwartney and Lawson (2004).

a 3.8-percentage point change of the relative life satisfaction differential; the respective figure for the latter indicator is 2.1 percentage points.

4.3.4 Corruption. Whether public employees acquire rents through corruption is empirically studied in column VIII of Table 1. The pervasiveness of corruption in a country is measured by an indicator that specifically captures bureaucratic corruption. It is based on a survey measuring perceptions of business executives about the frequency of irregular, additional payments, connected with import and export permits, business licenses, exchange controls, tax assessments, police protection, or loan applications (Gwartney and Lawson 2004). We find a close positive association between corruption and bureaucratic rents for the sample considered. Figure 2 visualizes the positive statistical association.

An increase of the corruption index by $1 \mathrm{SD}$ entails an increment in the life satisfaction differential of 4.7 percentage points, a magnitude comparable to the difference in the level of rents between Sweden on the one hand and Brazil on the other hand.

We tested the sensitivity of our results in a series of robustness checks. ${ }^{8}$ The results are very similar for a sample with less European countries, based on a combination of the LB with the EB instead of the ESS. Moreover, the

8. For the sake of brevity, the results are only reported in the unpublished data appendix (available on request). 
qualitative results do not depend on the weighting of observations. The relative life satisfaction differentials based on the EB are estimated with a higher precision compared to the ESS as the number of observations and the number of sampled bureaucrats exceed those of the ESS. Both robustness tests are, therefore, reassuring that the results are not driven by a combination of both imprecisely measured life satisfaction differentials and the weighting correction for heteroskedasticity.

\section{Concluding Remarks}

In this article, a new measure is introduced to directly approach the idea of rents in the public bureaucracy: the difference in life satisfaction between people working in the government sector and people working in the private sector within a country. We find that the relative advantage of working in the government sector differs substantially across countries. In accordance with theories on rent seeking, we find that the differences in rents can be partly accounted for by country differences in regulatory policies and differences in institutional constraints. Our proxy measure of rents also correlates with a widely used perceived corruption index. The fact that rents positively correlate with corruption shows that the benefits acquired through corruption are neither completely dissipated nor do they compensate for potentially lower regular salaries in the government sector.

Our new methodological approach can be applied to study other forms of rents outside of the government sector, where market imperfections have to be assessed. For example, it can be studied to what extent people exposed to environmental disadvantages are compensated on the housing and labor market. The approach can also be applied to study groups (e.g., minorities or women) that are potentially discriminated on the labor market. More generally, our analysis demonstrates that life satisfaction data can be applied to validate theories in law, economics, and politics in a new way.

\section{References}

Ades, Alberto, and Rafael Di Tella. 1999. "Rents, Competition, and Corruption," 89 American Economic Review 982-93.

Buchanan, James M. 1980. "Rent Seeking and Profit Seeking," in J.M. Buchanan, R.M. Tollison, and G. Tullock, eds., Toward a Theory of the Rent-Seeking Society. Texas: Texas A \& M University Press.

Buchanan, James M., and Gordon Tullock. 1962. The Calculus of Consent. Ann Arbor, Mich.: University of Michigan Press.

Clark, Andrew E., and Claudia Senik. 2004. "The (Unexpected) Structure of 'Rents' on the French and British Labour Markets.” 35 Journal of Socio-Economics 180-96.

de Figueiredo, Rui J. P., Jr., Pablo T. Spiller, and Santiago Urbiztondo. 1999. “An Informational Perspective on Administrative Procedures," 15 Journal of Law, Economics, and Organization 283-305.

Downs, Anthony. 1957. An Economic Theory of Democracy. New York: Harper.

Frey, Bruno S., and Alois Stutzer. 2002. "What Can Economists Learn from Happiness Research?," 40 Journal of Economic Literature 402-35. 
Gely, Rafael, and Pablo T. Spiller. 1990. “A Rational Choice Theory of Supreme Court Statutory Decisions with Applications to the State Farm and Grove City Cases," 6 Journal of Law, Economics, and Organization 263-300.

Graham, Carol, and Andy Felton. 2005. "Life Satisfaction in 17 Latin American Countries." Mimeo, Brookings Institution.

Gwartney, James D., and Robert A. Lawson. 2004. Economic Freedom of the World. Vancouver, Canada: The Fraser Institute.

Hanssen, F. Andrew. 2000. "Independent Courts and Administrative Agencies: An Empirical Analysis of the States," 16 Journal of Law, Economics, and Organization 534-71.

Henisz, Witold J. 2002. “The Institutional Environment for Infrastructure Investment,” 11 Industrial and Corporate Change 355-89.

Heston, Alan, Robert Summers, and Bettina Aten. 2002. "Penn Word Table 6.1." Mimeo, Center for International Comparisons, University of Pennsylvania.

Heywood, John S., W. Stanley Siebert, and Xiangdong Wei. 2002. "Worker Sorting and Job Satisfaction: The Case of Union and Government Jobs," 55 Industrial and Labor Relations Review 595-609.

Iaryczower, Matías, Pablo T. Spiller, and Mariano Tommasi. 2002. "Judicial Independence in Unstable Environments, Argentina 1935-1998," 46 American Journal of Political Science 699-716.

Kuniková, Jana, and Susan Rose-Ackerman. 2005. "Electoral Rules and Constitutional Structure as Constraints on Corruption," 35 British Journal of Political Science 573-606.

Landes, William M., and Richard A. Posner. 1975. “The Independent Judiciary in an InterestGroup Perspective," 18 Journal of Law and Economics 875-901.

Lupia, Arthur, and Mathew D. McCubbins. 1994. "Designing Bureaucratic Accountability," 57 Law and Contemporary Problems 91-126.

McChesney, Fred S. 1987. "Rent Extraction and Rent Creation in the Economic Theory of Regulation," 16 Journal of Legal Studies 101-18.

McCubbins, Mathew D., Roger G. Noll, and Barry R. Weingast. 1987. “Administrative Procedures as Instruments of Political Control," 3 Journal of Law, Economics, and Organization 243-77.

Moe, Terry M., and Michael Caldwell. 1994. "The Institutional Foundations of Democratic Government: A Comparison of Presidential and Parliamentary Systems," 150 Journal of Institutional and Theoretical Economics 171-95.

Olson, Mancur, Jr. 1982. The Rise and Decline of Nations. New Haven, Conn.: Yale University Press.

Persson, Torsten, and Guido Tabellini. 2004. "Constitutions and Economic Policy," 18 Journal of Economic Perspectives 75-98.

Rose-Ackerman, Susan. 1999. Corruption and Government. Cambridge, Mass.: Cambridge University Press.

Spiller, Pablo T. 1992. “Agency Discretion under Judicial Review," 16 Mathematical and Computer Modelling 185-200.

Spiller, Pablo T., and Santiago Urbiztondo. 1994. "Political Appointees vs. Career Civil Servants: A Multiple Principals Theory of Political Bureaucracies," 10 European Journal of Political Economy 465-97.

Tiller, Emerson H. 1998. "Controlling Policy by Controlling Process: Judicial Influence on Regulatory Decision Making,” 14 Journal of Law, Economics, and Organization 114-35.

Tiller, Emerson H., and Pablo T. Spiller. 1999. "Strategic Instruments: Legal Structure and Political Games in Administrative Law,” 15 Journal of Law, Economics, and Organization 349-77.

Tullock, Gordon. 1967. "Welfare Costs of Tariffs, Monopolies, and Theft," 5 Western Economic Journal 224-32.

Weingast, Barry R., and Mark J. Moran. 1983. "Bureaucratic Discretion or Congressional Control? Regulatory Policymaking by the Federal Trade Commission," 91 Journal of Political Economy 765-800. 